\title{
1-Methylcyclopropene Inhibits Degreening But Stimulates Respiration and Ethylene Biosynthesis in Grapefruit
}

\author{
Greg McCollum ${ }^{1}$ and Pilar Maul \\ USDA, ARS, USHRL, 2001 S. Rock Road, Ft. Pierce, FL 34945
}

Additional index words. Citrus paradisi, 1-MCP, color

\begin{abstract}
We determined the effects of 1-methylcyclopropene (1-MCP) and ethylene on color change and $\mathrm{CO}_{2}$ and ethylene production in grapefruit. Treatment with 1-MCP at concentrations equal to or greater than $75 \mathrm{~nL} \cdot \mathrm{L}^{-1}$ inhibited ethylene-induced degreening, but increasing 1-MCP concentrations greater than $150 \mathrm{~nL} \cdot \mathrm{L}^{-1}$ did not cause additional inhibition of degreening. Although ethylene-induced degreening was inhibited by 1-MCP, the effect was transient. Treating grapefruit with 15 to $75 \mathrm{~nL} \cdot \mathrm{L}^{-1} 1-\mathrm{MCP}$ resulted in a slight suppression of $\mathrm{CO}_{2}$ production, whereas treatment with 150 or $300 \mathrm{~nL} \cdot \mathrm{L}^{-1} 1-\mathrm{MCP}$ resulted in rates of $\mathrm{CO}_{2}$ production significantly higher than nontreated fruit. 1-MCP treatment also caused a very pronounced increase in the rate of $\mathrm{C}_{2} \mathrm{H}_{4}$ production that was both dose- and time-dependent. The effects of 1-MCP on respiration and ethylene evolution were reduced if fruit was subsequently exposed to ethylene. Fruit treated with 1-MCP alone had the highest rates of $\mathrm{CO}_{2}$ production, fruit treated with ethylene after 1-MCP or ethylene alone had intermediate rates of $\mathrm{CO}_{2}$ production, and control fruit had the lowest rate of $\mathrm{CO}_{2}$ production. Rates of $\mathrm{C}_{2} \mathrm{H}_{4}$ evolution were $\approx 200 \mathrm{~nL} \cdot \mathrm{kg}^{-1} \cdot \mathrm{h}^{-1}$ from control and $\mathrm{C}_{2} \mathrm{H}_{4}$-treated fruit compared with $\approx 10,000 \mathrm{~nL} \cdot \mathrm{kg}^{-1} \cdot \mathrm{h}^{-1}$ from 1-MCP-treated fruit; fruit treated with ethylene after 1-MCP had ethylene production rates of $\approx 400 \mathrm{~nL} \cdot \mathrm{kg}^{-1} \cdot \mathrm{h}^{-1}$. Our results lend further support for a regulatory role for ethylene in degreening of citrus and suggest that endogenous levels of ethylene regulate ethylene production.
\end{abstract}

Grapefruit (Citrus paradisi), like all citrus fruits, produce very low levels of ethylene throughout development and do not exhibit an ethylene climacteric during ripening (Aharoni, 1968; Eaks, 1970). Citrus fruit do exhibit elevated levels of ethylene production in response to a variety of stresses, including wounding (Evenson et al., 1981; Hyodo, 1977; Riov and Yang, 1982), low temperature (Eaks, 1980; McCollum and McDonald, 1991), and infection by pathogens (Achilea et al., 1984; Mullins et al., 2000).

Exposure of citrus fruit to exogenous ethylene induces a number of physiological and biochemical changes, including increases in activity of phenylalanine ammonia lyase (Riov et al., 1969), cholorophyllase (Trebitsh et al., 1993), and cellulase (Kazokas and Burns, 1998), alteration of protein complement (Alonso et al., 1992), and gene expression (Alonso et al., 1995; Alonso and Granell, 1995; Jacob-Wilk et al., 1997, 1999; Kazokas and Burns, 1998). Eaks (1970) reported that exposure of citrus fruits to ethylene resulted in a temporary and repeatable increase in respiration. Ethylene will

\footnotetext{
Received for publication 16 May 2006. Accepted for publication 22 June 2006.

The technical assistance of Mr. John Prokop is gratefully acknowledged.

${ }^{1}$ To whom reprint requests should be addressed; e-mailgmccollum@ushrl.ars.usda.gov.
}

also induce abscission of citrus fruits (Goren, 1993). Most notable among the responses of citrus fruits to exogenous ethylene is the loss of chlorophyll (Eilati and Goldschmidt, 1969; Garcia-Luis et al., 1986; Goldschmidt et al., 1977; Purvis and Barmore, 1981; Shimokawa et al., 1978) or "degreening" of commercial practice (Grierson et al., 1986).

Goldschmidt (1997) has pointed out that the lack of a ripening-associated autocatalytic rise in ethylene does not rule out a role for ethylene in the development of nonclimacteric fruits. Several lines of evidence indicate that ethylene does have a regulatory role in citrus fruit physiology. First is the effect of exogenous ethylene on wound-induced ethylene. Exposure of citrus peel discs to ethylene results in the inhibition of woundinduced ethylene, the result of a suppression of ACC, the immediate precursor of ethylene (Riov and Yang, 1982), and suppression of ACC synthase messenger RNA (Mullins et al., 1999). Second is the effect of inhibitors of ethylene action on ethylene-related responses. Goldschmidt et al. (1993) used the ethylene antagonists 2,5-norbornadiene and silver nitrate to block ethylene action and were able to confirm the role of endogenous ethylene in degreening of citrus fruit. More recently, studies with the ethylene action inhibitor 1-methylcyclopropene (1-MCP) (Blankenship and Dole, 2003) have strengthened evidence for a role of endogenous ethylene in citrus fruit physiology. Porat et al. (1999) reported that treatment of 'Shamouti' oranges with 1-MCP completely inhibited ethylene-enhanced degreening. In contrast to oranges, neither ethylene nor 1-MCP had significant effect on color change in 'Oroblanco' a pummelo $\times$ grapefruit hybrid (Porat et al., 2001). Treatment with 1-MCP will also inhibit ethylene-induced abscission in citrus (Sisler et al., 1999; Zhong et al., 2001). Curiously, treatment of citrus rind discs (Mullins et al., 1999; Sisler et al., 1999) and leaves (Zhong et al., 2001) with 1-MCP has been reported to actually stimulate the production of ethylene while at the same time inhibiting the response to ethylene. That treatment with 1-MCP stimulates ethylene production indicates the perception of endogenous ethylene regulates the production of ethylene in citrus. The stimulation of ethylene production by 1-MCP has only been reported for wounded tissues; it is not known if treatment with 1-MCP elicits similar responses in nonwounded tissue. Our objectives in the work presented here were to determine the effects of 1-MCP treatment on ethylene-induced physiological changes in intact grapefruit.

\section{Materials and Methods}

\section{Plant material}

'Marsh' grapefruit harvested from a commercial grove were used in all studies. Fruit was harvested in August and September before color break. Treatment with 1-MCP was conducted within $24 \mathrm{~h}$ after harvest.

The number of fruit used for each experimental unit ranged from 5 to 15 depending on the experiment.

\section{Treatments with 1-MCP and ethylene}

Treatment with 1-MCP was conducted in 200-L steel chambers. Five milliliters of water containing $0.5 \%(\mathrm{w} / \mathrm{v})$ sodium dodecyl sulfate was added to the appropriate amount of EthylBloc (0.14\%1-MCP) (Biotechnologies for Horticulture, Inc., Waltersboro, S.C.) to give the desired concentration of 1-MCP gas $\left(15-3000 \mathrm{~nL} \cdot \mathrm{L}^{-1}\right)$. The solutions were placed into chambers containing the fruit and the top of the chambers sealed with gasketed lids. The chambers were held at $25{ }^{\circ} \mathrm{C}$ for $24 \mathrm{~h}$. Treatment with ethylene $\left(5 \mu \mathrm{L} \cdot \mathrm{L}^{-1}\right)$ was done at $25^{\circ} \mathrm{C}$ in a room with one air exchange per hour.

Five separate experiments were conducted. The objective of the first two experiments was to determine the effects of 1-MCP dose on color loss of grapefruit peel. In the first experiment, grapefruit were exposed to $0,15,30,75,150$, or $300 \mathrm{~nL} \cdot \mathrm{L}^{-1} 1-\mathrm{MCP}$ for $24 \mathrm{~h}$ After treatment with $1-\mathrm{MCP}$, the fruit was transferred to air containing $5 \mu \mathrm{L} \cdot \mathrm{L}^{-1}$ ethylene for up to $72 \mathrm{~h}$. Fruit rind color was measured after $0,24,48$, and $72 \mathrm{~h}$ in ethylene. The second experiment was conducted exactly as the first but with 1-MCP concentrations of $0,150,300,750,1500$, and $3000 \mathrm{~nL} \cdot \mathrm{L}^{-1}$. The objective of the third experiment was to determine the effects of 1-MCP dose on grapefruit respiration and ethylene evolution. 
Fruits were exposed to $1-\mathrm{MCP}\left(300 \mathrm{~nL} \cdot \mathrm{L}^{-1}\right)$ as described previously but, after exposure to 1-MCP, were transferred to air rather than air containing ethylene. At $0,24,48$, and $72 \mathrm{~h}$ after transfer, rates of $\mathrm{CO}_{2}$ and ethylene evolution from the fruit were measured. The objective of the fourth experiment was to determine the effects of duration of 1-MCP or ethylene exposure on $\mathrm{CO}_{2}$ and ethylene evolution from grapefruit. Fruit were held in air, ethylene $\left(5 \mu \mathrm{L} \cdot \mathrm{L}^{-1}\right)$, or $1-\mathrm{MCP}\left(300 \mathrm{~nL} \cdot \mathrm{L}^{-1}\right)$ for up to $72 \mathrm{~h}$. Fruit was removed from the treatments at 24-h intervals and held in air at $25{ }^{\circ} \mathrm{C} ; \mathrm{CO}_{2}$ and ethylene production were measured 24,48 , and $72 \mathrm{~h}$ after transfer to air. The objective of the fifth experiment was to determine the effects of 1-MCP $\left(300 \mathrm{~nL} \cdot \mathrm{L}^{-1}\right)$ alone, 1-MCP followed by ethylene, or ethylene alone on color change, $\mathrm{CO}_{2}$, and ethylene evolution. Fruit was divided into two groups; one group was treated with 1-MCP for $24 \mathrm{~h}$ and the second group held in air for $24 \mathrm{~h}$. After the initial 24-h treatment, the two treatment groups were divided into two subgroups; one subgroup from each of the original groups was transferred to air and the second subgroup from each of the original groups was transferred to air containing $5 \mu \mathrm{L} \cdot \mathrm{L}^{-1}$ ethylene. The ethylene treatment was done for $72 \mathrm{~h}$, after which the fruit was transferred to air. During the course of treatment, peel color was measured at 24-h intervals. Twenty-four hours after transfer of the ethylene-treated fruit to air, $\mathrm{CO}_{2}$ and ethylene evolution were determined from fruit in each of the four treatment groups.

\section{Color}

Fruit peel color (three readings per fruit) was determined using a Minolta chromometer (model CR-300; Minolta Camera Corp., Osaka, Japan). The Commission Internationale de 1'Eclairage $\mathrm{a}^{*}$ and $\mathrm{b}^{*}$ color index scale was used and peel color expressed as $\mathrm{a}^{*} / \mathrm{b}^{*}$ ratio.

\section{Carbon dioxide and ethylene production}

Evolution of carbon dioxide and ethylene from whole fruit was determined using a static system. Fruit were sealed in $1.8-\mathrm{L}$ glass jars with lids fitted with rubber septa. Fruit were incubated at $20{ }^{\circ} \mathrm{C}$ for $\approx 1 \mathrm{~h}$ for $\mathrm{CO}_{2}$ determination and $\approx 3 \mathrm{~h}$ for ethylene. Headspace samples were collected and analyzed by gas chromatography (McCollum and McDonald, 1991). A thermal conductivity detector was used for the detection of $\mathrm{CO}_{2}$ and a flame ionization detector for the detection of $\mathrm{C}_{2} \mathrm{H}_{4}$.

\section{Results}

Effects of 1-MCP at concentrations from 15 to $3000 \mathrm{~nL} \cdot \mathrm{L}^{-1}$ on ethylene-induced degreening of 'Marsh' grapefruit were determined in the first two experiments. Treatment of 'Marsh' grapefruit with 1-MCP at concentrations of $75 \mathrm{~nL} \cdot \mathrm{L}^{-1}$ or greater for $24 \mathrm{~h}$ resulted in inhibition of ethylene-induced degreening during $48 \mathrm{~h}$ in ethylene and an additional $24 \mathrm{~h}$ in air (Fig. 1A); however, increasing the concentration of 1-MCP to greater than $75 \mathrm{~nL} \cdot \mathrm{L}^{-1}$ did not result in further inhibition of degreening (Fig. 1B).

There was no significant difference in $\mathrm{CO}_{2}$ production among grapefruit that had been treated with 1-MCP at concentrations from 0 to $300 \mathrm{~nL} \cdot \mathrm{L}^{-1}$ for $24 \mathrm{~h}$ at the time of transfer to air (Fig. 2). Twenty-four h after transfer to air, $\mathrm{CO}_{2}$ production from fruit that had been treated with 15 to $150 \mathrm{~nL} \cdot \mathrm{L}^{-1}$ 1-MCP was slightly, but significantly, lower than from fruit that had been treated with 0 or $300 \mathrm{~nL} \cdot \mathrm{L}^{-1} 1$-MCP. At $48 \mathrm{~h}$ after 1-MCP treatment, $\mathrm{CO}_{2}$ production from fruit that had been treated with 1-MCP at concentrations of 150 or $300 \mathrm{~nL} \cdot \mathrm{L}^{-1}$ was significantly higher than from all other treatments, whereas $\mathrm{CO}_{2}$ production from fruit treated with 15 or $30 \mathrm{~nL} \cdot \mathrm{L}^{-1} 1-\mathrm{MCP}$ was lower than from fruit not exposed to 1-MCP. Seventy-two $h$ after transfer to air, $\mathrm{CO}_{2}$ production from grapefruit that had been treated with 75 to 300 $\mathrm{nL} \cdot \mathrm{L}^{-1} 1-\mathrm{MCP}$ was significantly higher than from fruit that had been treated with 0 $30 \mathrm{~nL} \cdot \mathrm{L}^{-1} 1-\mathrm{MCP}$.

Ethylene production from 'Marsh' grapefruit also exhibited a dose-dependent response to 1-MCP; however, the pattern of the response was considerably different than for $\mathrm{CO}_{2}$ (Fig. 2B). At the time of transfer from 1-MCP to air, ethylene production was significantly higher in fruit treated with 150 or $300 \mathrm{~nL} \cdot \mathrm{L}^{-1} 1-\mathrm{MCP}$ than in all other fruit. Twenty-four $\mathrm{h}$ after transfer to air, all fruit treated with 1-MCP were producing greater amounts of ethylene than were fruit not exposed to 1-MCP. In addition, the amount of ethylene being produced increased with increasing dose of 1-MCP. Ethylene production increased and reached its maximum between 24 and $48 \mathrm{~h}$ after treatment from fruit that had been exposed to $1-\mathrm{MCP}$ at concentrations of $75 \mathrm{~nL} \cdot \mathrm{L}^{-1}$ or greater. After transferring to air (48-72 $\mathrm{h}$ after exposure to $1-\mathrm{MCP}$ ), the rate of ethylene production decreased sharply; however, it was still significantly higher than in fruit that had been exposed to 0 or $15 \mathrm{~nL} \cdot \mathrm{L}^{-1} 1-\mathrm{MCP}$.

The effects of duration of ethylene $\left(5 \mu \mathrm{L} \cdot \mathrm{L}^{-1}\right)$ or 1 -MCP $\left(300 \mathrm{~nL} \cdot \mathrm{L}^{-1}\right)$ treatment on rates of $\mathrm{CO}_{2}$ and ethylene evolution from 'Marsh' grapefruit are presented in Fig. 3. In general, compared with controls, treatment with ethylene resulted in only a slight increase in $\mathrm{CO}_{2}$ evolution and only if the duration of treatment exceeded $24 \mathrm{~h}$. Rates of ethylene evolution from ethylene-treated fruit were for the most part similar to those of control fruit regardless of treatment duration or time after treatment (Fig. 3B, D, F). The response of 'Marsh' grapefruit to treatment with $1-\mathrm{MCP}$, in contrast to ethylene, was very pronounced. Fruit treated with 1-MCP for $24 \mathrm{~h}$ had rates of $\mathrm{CO}_{2}$ evolution less than control fruit $24 \mathrm{~h}$ after transfer to air but, at 48 and $72 \mathrm{~h}$ after transfer, had rates of $\mathrm{CO}_{2}$ evolution greater than control fruit (Fig. 3A). Fruit treated with 1-MCP for 48 or $72 \mathrm{~h}$ had rates of $\mathrm{CO}_{2}$ evolution that were consistently higher than controls (Fig. 3C, E). Additionally, rates of $\mathrm{CO}_{2}$ evolution from 1-MCP-
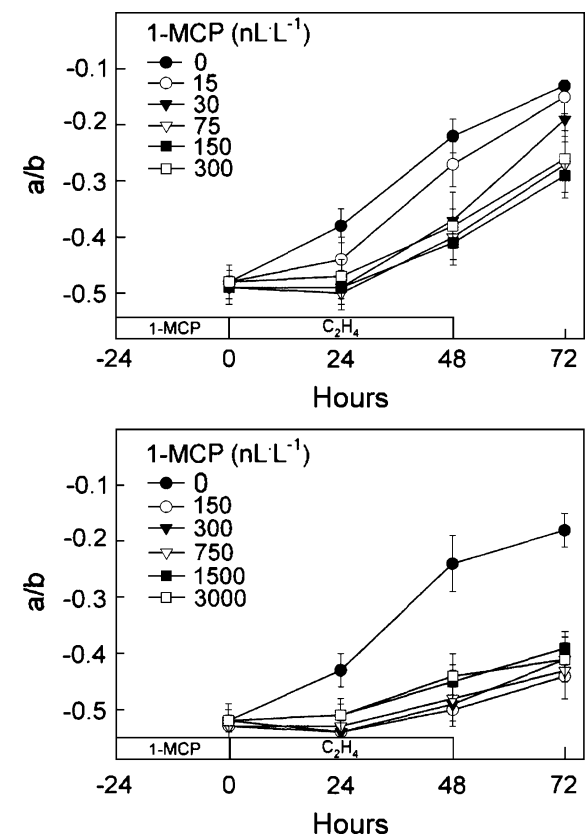

Fig. 1. Effect of 1-MCP dose (A, 0-300 nL. $\mathrm{L}^{-1}$ treatment; B, 0-3000 $\left.\mathrm{nL} \cdot \mathrm{L}^{-1}\right)$ on ethylene-induced degreening of 'Marsh' grapefruit. Fruit was held at $25^{\circ} \mathrm{C}$ in the indicated concentrations of 1-MCP for $24 \mathrm{~h}$ and then transferred to air containing $5 \mu \mathrm{L} \cdot \mathrm{L}^{-1}$ ethylene at $25{ }^{\circ} \mathrm{C}$. Values represent the means of 15 fruit. Vertical bars indicate standard error of the mean.
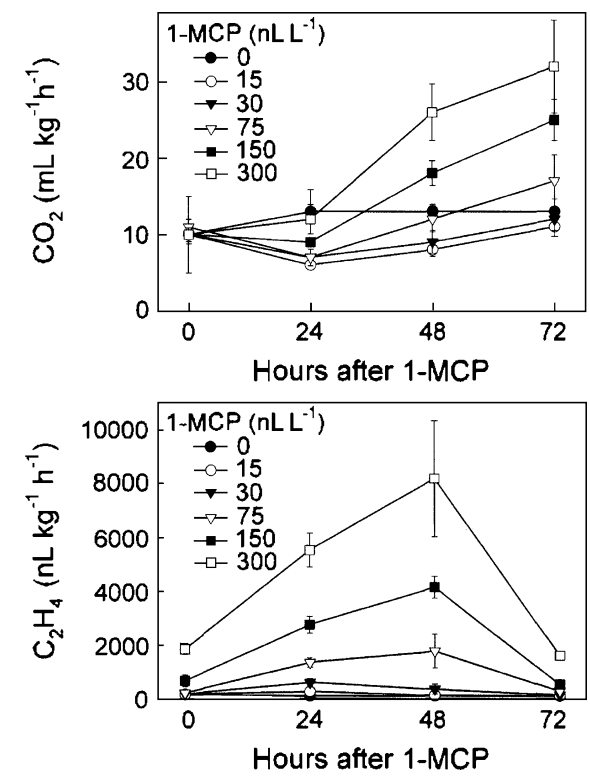

Fig. 2. Effects of 1-MCP treatment on rates of (A) $\mathrm{CO}_{2}$ and (B) ethylene evolution from 'Marsh' grapefruit. Fruit was treated as described in Figure 1. After 1-MCP treatment, fruit was transferred to $1-\mathrm{MCP}$ free air at $25^{\circ} \mathrm{C}$ and $\mathrm{CO}_{2}$ and ethylene evolution measured every $24 \mathrm{~h}$. Values represent means of three fruit. Vertical bars indicate standard error of the mean.

traeted fruit increased with time after transfer to air regardless of treatment duration (Fig. 3A, C, E). Effects of 1-MCP treatment on ethylene evolution from 'Marsh' grapefruit were quite dramatic. Ethylene evolution increased both with increased duration of 

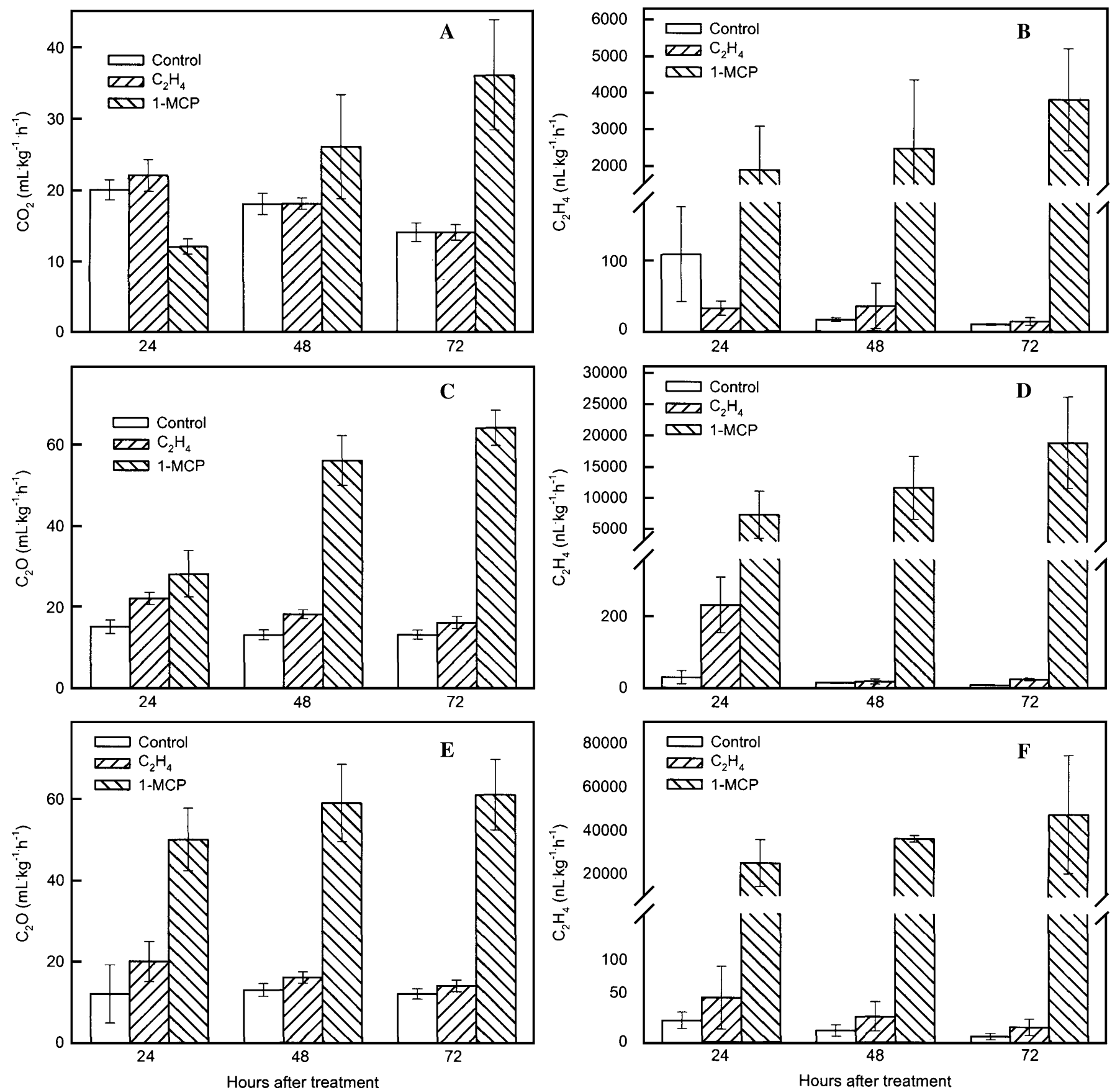

Fig. 3. Effects of duration of exposure to ethylene or 1-MCP on rates of $\mathrm{CO}_{2}$ and ethylene evolution from 'Marsh' grapefruit. Fruit was treated for (A and $\left.\mathbf{B}\right) 24$ h, (C and D) 48 hours, or (E and $\mathbf{F}$ ) $72 \mathrm{~h}$ and then transferred to air. At 24, 48, and $72 \mathrm{~h}$ after transfer to air, rates of $\mathrm{CO}_{2}$ and ethylene evolution were measured. Bars represent the average of 5 fruit \pm standard deviation.

1-MCP treatment as well as with time after treatment (Fig. 3B, D, F).

In another set of experiments, we determined the effects of $1-\mathrm{MCP}\left(300 \mathrm{~nL} \cdot \mathrm{L}^{-1}, 24 \mathrm{~h}\right.$ at $25{ }^{\circ} \mathrm{C}$ ) alone or followed by ethylene $\left(5 \mu \mathrm{L} \cdot \mathrm{L}^{-1}, 72 \mathrm{~h}\right.$ at $\left.25^{\circ} \mathrm{C}\right)$. We also followed color changes in the fruit for a greater duration ( $3 \mathrm{~d}$ vs. $1 \mathrm{~d}$ ) after ethylene treatment than in the first experiments. Treatment of 'Marsh' grapefruit with $300 \mathrm{~nL} \cdot \mathrm{L}^{-1} 1-\mathrm{MCP}$ for $24 \mathrm{~h}$ inhibited the effect of ethylene-enhanced degreening, but the effect was only temporary because 1-MCP-treated fruit eventually attained nearly the same color as did the nontreated fruit (Fig. 4). Color of grapefruit treated with 1-MCP alone was similar to control fruit and lower than for fruit that were exposed to ethylene ( $\pm 1-\mathrm{MCP})$. However, $a / b$ ratios increased for both control and 1-MCP-treated fruit during the experiment.

Treatment with ethylene for $48 \mathrm{~h}$ after 1-MCP resulted in a suppression of 1-MCPinduced increases in $\mathrm{CO}_{2}$ and $\mathrm{C}_{2} \mathrm{H}_{4}$ evolution. Rates of $\mathrm{CO}_{2}$ evolution were highest in 1-MCP-treated fruit, intermediate and similar in fruit treated with $\mathrm{C}_{2} \mathrm{H}_{4}$ either with or without previous treatment with 1-MCP, and lowest in control fruit (Fig. 5A). Treatment with 1-MCP alone resulted in a 50-fold increase in $\mathrm{C}_{2} \mathrm{H}_{4}$ evolution compared with a roughly doubling of $\mathrm{C}_{2} \mathrm{H}_{4}$ production in fruit treated with ethylene after 1-MCP (Fig. $5 B$ ). The rate of $\mathrm{C}_{2} \mathrm{H}_{4}$ evolution from $\mathrm{C}_{2} \mathrm{H}_{4}$ treated fruit was slightly higher than from control fruit.

\section{Discussion}

The role of ethylene in the development of nonclimacteric fruits has received much less attention than for climacteric fruits. However, it is well known that citrus, as well as other nonclimacteric fruits, respond to treatment with ethylene (Goldschmidt, 1997) and that antagonists of ethylene action can inhibit 


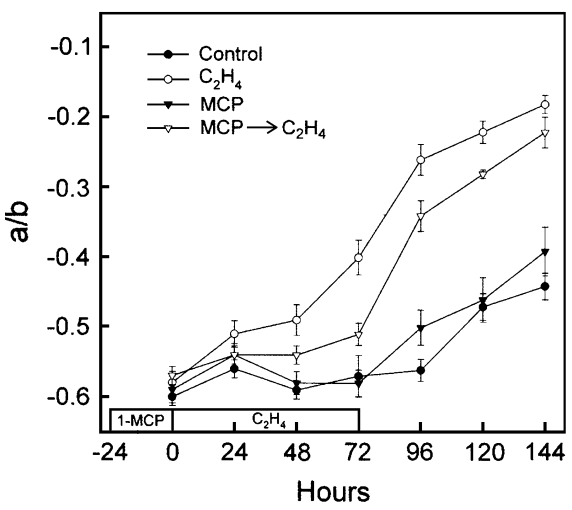

Fig. 4. Effects of 1-MCP, 1-MCP followed by ethylene, or ethylene alone on degreening of 'Marsh' grapefruit. Fruit was held at $25{ }^{\circ} \mathrm{C}$ in either air or air containing $300 \mathrm{nl} \cdot \mathrm{L}^{-1} 1-\mathrm{MCP}$ for $24 \mathrm{~h}$ and then transferred to air containing $5 \mu \mathrm{L} \cdot \mathrm{L}^{-1} \mathrm{ppm}$ at $25{ }^{\circ} \mathrm{C}$ for $72 \mathrm{~h}$. After ethylene treatment, fruit was transferred to air free of ethylene at $25{ }^{\circ} \mathrm{C}$.

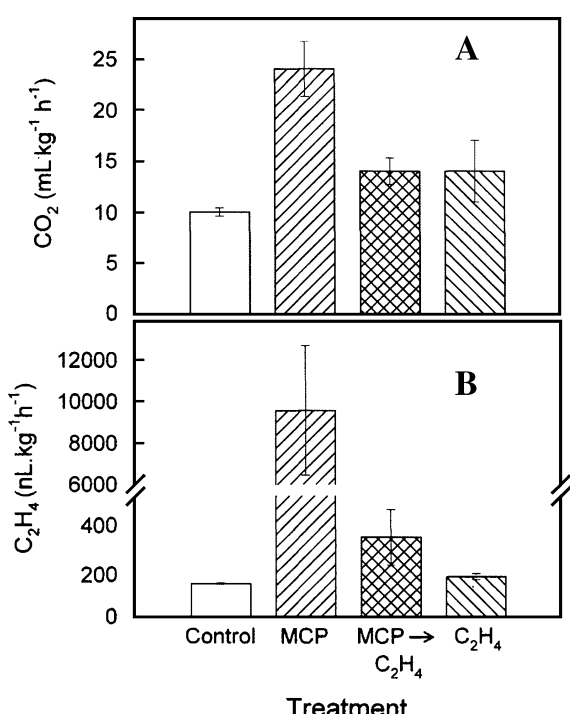

Fig. 5. Effects of 1-MCP, ethylene, and 1-MCP + ethylene on (A) $\mathrm{CO}_{2}$ and (B) ethylene production from 'Marsh' grapefruit. Fruit was treated as described in Figure 4. $\mathrm{CO}_{2}$ and ethylene production was determined after $48 \mathrm{~h}$ in ethylene-free air.

normal developmental changes in citrus (Goldschmidt et al., 1993; Sisler et al., 1999; Zhong et al., 2001) lending further support for the role of ethylene.

Ethylene treatment leads to the loss of green color in grapefruit (Figs. 1 and 4) and other citrus fruits (Eilati and Goldschmidt, 1969; Garcia-Luis et al., 1986; Goldschmidt et al., 1977; Purvis and Barmore, 1981; Shimokawa et al., 1978). The effect of ethylene on color change in citrus fruit has been shown to be related to an increase in chlorophyllase activity (Purvis and Barmore, 1981; Shimokawa et al., 1978; Trebitsh et al., 1993) and also an increase in the abundance of chlorophyllase messenger RNA (JacobWilk et al., 1999). In addition, treatments that inhibit ethylene action have been shown to in- hibit degreening of citrus fruit (Goldschmidt et al., 1993; Porat et al., 1999). Interestingly, 'Oroblaco' (a grapefruit $\times$ pummelo hybrid) fruit show very little color change in response to ethylene treatment and no response to 1-MCP (Porat et al., 2001). Our results with grapefruit fall somewhere in between results with oranges and 'Oroblanco' in that treatment with ethylene does lead to a significant loss of green color and treatment with 1-MCP causes a delay in that loss, but the effect does not persist (Fig. 4).

Although few reports document the effects of 1-MCP on respiration, in those that do, there has been a suppression of respiration (Blankenship and Dole, 2003 and references therein). We found that 1-MCP can inhibit or stimulate $\mathrm{CO}_{2}$ production in grapefruit depending on dose and time after treatment. Grapefruit treated with 15 or $30 \mathrm{~nL} \cdot \mathrm{L}^{-1}$ 1-MCP for $24 \mathrm{~h}$ had lower rates of $\mathrm{CO}_{2}$ production than did control or fruit treated with $1-\mathrm{MCP}$ at rates of $75 \mathrm{~nL} \cdot \mathrm{L}^{-1}$ and higher (Figs. 2a and 3A). The 1-MCP-induced increase in respiration was reduced if fruit was subsequently treated with ethylene (Fig. 5A). Ethylene has been reported to cause a transient increase in respiration rates of grapefruit (Eaks, 1970). We found that $\mathrm{CO}_{2}$ production from ethylene-treated grapefruit was only slightly higher than from control fruit (Figs. 3A, C, E and 5A). How ethylene can inhibit the 1-MCP-induced increase in respiration is difficult to explain.

Treatment with 1-MCP has typically resulted in a suppression of ethylene evolution from a variety of plant tissues (Blankenship and Dole, 2003 and references therein). However, 1-MCP treatment has been reported to increase wound-induced ethylene production (Mathooko et al., 2001; Mullins et al., 2000; Owino et al., 2002). It has also been reported that 1-MCP enhances ethylene biosynthesis in leaves of coriander (Jiang et al., 2002) and parsley (Ella et al., 2003). In the current study, we also found that 1-MCP induces ethylene biosynthesis in grapefruit in a dose-dependent manner (Fig. 2B). In parsley leaves, 1-MCP caused a rapid increase in ethylene evolution followed by a gradual decrease (Ella et al., 2003). The effect of 1-MCP on grapefruit, a nonclimacteric fruit, seems to be similar to that observed for leaf tissue and system 1 ethylene in climacteric fruit (Barry et al., 2000; Nasatsuka et al., 1998). Although ethylene has been found to be autoinhibitory in citrus rind discs (Mullins et al., 1999; Riov and Yang, 1982), in the present study, we found that ethylene production from ethylenetreated intact grapefruit tended to be slightly higher than for nonethylene treated fruit (Figs. 3B, D, F and 5B), although this was not entirely consistent. This suggests that the regulation of wound-induced ethylene differs from the regulation of ethylene in nonwounded tissue in citrus fruit. Blocking the perception of ethylene leads to a massive increase in ethylene biosynthesis (Figs. 2B, $3 \mathrm{~B}, \mathrm{D}, \mathrm{F}$ and $5 \mathrm{~B}$ ), whereas exposure to a low dose of ethylene results in a slight stimulation of ethylene biosynthesis.
Blocking the perception of ethylene with 1-MCP has pronounced effects on grapefruit physiology. These results lend further support for a regulatory role for ethylene in citrus fruit development. Although the potential for using 1-MCP as a postharvest treatment to reduce losses of citrus fruit is doubtful, studies with 1-MCP can provide insight into the effects of endogenous ethylene on citrus fruit.

\section{Literature Cited}

Achilea, O., E. Chalutz, Y. Fuchs, and I. Rot. 1984. Ethylene biosynthesis and related physiological changes in Penicillium digitatum-infected grapefruit (Citrus paradisi). Physiol. Plant Path. 26:125-134.

Aharoni, Y. 1968. Respiration of oranges and grapefruits harvested at different stages of development. Plant Physiol. 43:99-102.

Alonso, J.M. and A. Granell. 1995. A putative vacuolar processing protease is regulated by ethylene and also during fruit ripening in citrus fruit. Plant Physiol. 109:541-547.

Alonso, J.M., J. Chamarro, and A. Granell. 1995. Evidence for the involvement of ethylene in the expression of specific RNAs during maturation of the orange, a non-climacteric fruit. Plant Mol. Biol. 29:385-390.

Alonso, J.M., J.L. Garcia-Martinez, and J. Chamarro. 1992. Two dimensional gel electrophoresis patterns of total, in vivo labeled and in vitro translated polypeptides from orange flavedo during maturation and following ethylene treatment. Physiol. Plant. 85:147-156.

Barry, C.S., M.I. Llop-Tous, and D. Grierson. 2000. The regulation of 1-aminocyclopropane-1-carboxylic acid synthase during the transition from system-1 to system-2 ethylene synthesis in tomato. Plant Physiol. 123:979986.

Blankenship, S.M. and J.M. Dole. 2003. 1-Methylcyclopropene: A review. Posthar. Biol Tech. 28:1-25.

Eaks, I.I. 1970. Respiratory response, ethylene production, and response to ethylene of citrus fruit during ontogeny. Plant Physiol. 45:334 338 .

Eaks, I.I. 1980. Effect of chilling on respiration and volatiles of California lemon fruit. Plant Physiol. 105:865-869.

Eilati, S.K. and E.E. Goldschmidt. 1969. Hormonal control of color change in orange peel. Experientia 25:209-210.

Ella, L., A. Zion, A. Nehemia, and A. Lers. 2003. Effect of the ethylene action inhibitor 1-methylcyclopropene on parsley leaf senescence and ethylene biosynthesis. Postharvest Biol. Technol. 30:67-74.

Evenson, K., M.G. Bausher, and R.H. Biggs. 1981. Wound-induced ethylene production in peel explants of 'Valencia' orange fruit. HortScience 16:43-44.

Garcia-Luis, A., F. Fornes, and J.L. Guardiola. 1986. Effects of gibberrellin A3 and cytokinins on natural and post-harvest, ethylene-induced pigmentation of Satsuma manarin peel. Physiol. Plant. 68:271-274.

Goldschmidt, E.E. 1997. Ripening of citrus and other non-climacteric fruits: A role for ethylene. Acta Hort. 463:335-340.

Goldschmidt, E.E., Y. Aarón, S.K. Eilati, J. Riov, and S.P. Monselise. 1977. Differential counteraction of ethylene effects by gibberrellin $\mathrm{A}_{3}$ and N6-benzyadenine in senescing citrus peel. Plant Physiol. 59:193-195. 
Goldschmidt, E.E., M. Huberman, and R. Goren. 1993. Probing the role of endogenous ethylene in the degreening of citrus fruit with ethylene antagonists. Plant Growth Reg. 12:325-329.

Goren, R. 1993. Anatomical, physiological, and hormonal aspects of abscission in citrus. Hort. Rev. (Amer. Soc. Hort. Sci.) 15:145-181.

Grierson, W., E. Cohen, and H. Kitagawa. 1986. Degreening, p. 254-274. In: W. Wardowski, S. Nagy, and W. Grierson (eds.). Fresh citrus fruits. AVI, Westport, Conn.

Hyodo, H. 1977. Ethylene production by albedo tissue of Satsuma mandarin (Citrus unshiu Marc.) fruit. Plant Physiol. 59:111-113.

Jacob-Wilk, D., D. Holland, E.E. Goldschmidt, J. Riov, and Y. Eyal. 1999. Chlorophyll breakdown by chlorophyllase: Isolation and functional expression of the Chlasel gene from ethylene-treated citrus fruit and its regulation during development. Plant J. 20:653-661.

Jacob-Wilk, D., E.E. Goldschmidt, J. Riov, A. Sadka, and D. Holland. 1997. Induction of a citrus gene highly homologous to plant and yeast thi genes involved in thiamine biosynthesis during natural and ethylene-induced fruit maturation. Plant Mol. Biol. 35:661-666.

Jiang, W., Q. Sheng, X. Shou, M. Zhang, and X. Liu. 2002. Regulation of detached coriander leaf senescence by 1-methylcyclopropen and ethylene. Postharvest Biol Technol. 26: 339-405.

Kazokas, W.C. and J.K. Burns. 1998. Cellulase activity and gene expression in citrus fruit abscission zones during and after ethylene treatment. J. Amer. Soc. Hort. Sci. 123:781-786.
Mathooko, F.M., Y. Tsunashima, W.Z.O. Owino, Y. Kubo, and A. Inaba. 2001. Regulation of genes encoding ethylene biosynthetic enzymes in peach (Prunus persica L.) fruit by carbon dioxide and 1-methylecyclopropene. Postharvest Biol. Technol. 21:265-281.

McCollum, T.G. and R.E. McDonald. 1991. Electrolyte leakage, respiration, and ethylene as indices of chilling injury in grapefruit. HortScience 26:1191-1192.

Mullins, E.D., T.G. McCollum, and R.E. McDonald. 1999. Ethylene: a regulator of stress-induced ACC synthase activity in nonclimacteric fruit. Physiol. Plant. 107:1-7.

Mullins, E.D., T.G. McCollum, and R.E. McDonald. 2000. Consequences on ethylene metabolism of inactivating the ethylene receptor sites in diseased non-climacteric fruit. Postharvest Biol. Tech. 19:155-164.

Nasatsuka, A., S. Murachi, H. Okunishi, S. Shiomi, R. Nakano, Y. Kubo, and A. Inaba. 1998. Differential expression and internal feedback regulation of 1-amniocyclopropane-1-carboxylate synthase, 1-aminocyclopropane-1-carboxylate oxidase and ethylene receptor genes in tomato fruit during development and ripening. Plant Physiol. 118:1295-1305.

Owino, W.O., R. Nakano, Y. Kubo, and A. Inaba 2002. Differential regulation of genes encoding ethylene biosynthesis enzymes and ethylene response sensor ortholog during ripening and in response to wounding in avocados. J. Amer. Soc. Hort. Sci. 127:520-527.

Porat, R., X. Feng, M. Huberman, D. Galili, R. Goren, and E.E. Goldschmidt. 2001. Gibberellic acid slows postharvest degreening of 'Oroblanco' citrus fruits. HortScience 36:937-940.

Porat, R., B. Weiss, L. Cohen, A. Daus, R. Goren, and S. Droby. 1999. Effects of ethylene and 1methylcyclopropene on the postharvest qualities of 'Shamouti' oranges. Postharvest Biol Tech. 15:155-163.

Purvis, A. and C. Barmore. 1981. Involvement of ethylene in chlorophyll degradation in peel of citrus fruit. Plant Physiol. 68:854-856.

Riov, J. and S.F. Yang. 1982. Autoinhibition of ethylene production in citrus peel discs. Plant Physiol. 69:687-690.

Riov, J., S.P. Monselise, and R.S. Kahan. 1969. Ethylene-controlled induction of phenylalanine ammonia-lyase in citrus fruit peel. Plant Physiol. 44:631-635.

Shimokawa, K., S. Shimade, and K. Yaeo. 1978. Ethylene-enhanced chlorophyllase activity during degreening of Citrus unshiu Marc. Sci. Hort. (Amsterdam) 8:129-135.

Sisler, E.C., M. Serek, E. Dupille, and R. Goren. 1999. Inhibition of ethylene responses by 1-methylcyclopropene and 3-methylcyclopropene. Plant Growth Regulat. 27:105111.

Trebitsh, T., E.E. Goldschmidt, and J. Riov. 1993. Ethylene induces de novo synthesis of chlorophyllase, a chlorophyll degrading enzyme, in Citrus fruit peel. Proc. Natl. Acad. Sci. USA 90:9441-9445.

Zhong, G.Y., M. Huberman, X.Q. Feng, E.C. Sisler, D. Holland, and R. Goren. 2001. Effect of 1-methylcyclopropene on ethylene-induced abscission in citrus. Physiol. Plant. 113:134-14. 